\title{
A MICRO CELL LYSIS DEVICE
}

\author{
S. W. Lee, H. Yowanto ${ }^{*}$ and Y. C. Tai \\ Caltech Micromachining Laboratory, \\ Electrical Engineering, 136-93, \\ California Institute of Technology, \\ Pasadena, CA 91125, USA \\ "Clinical Micro Sensors, Inc., \\ 101 Waverly Drive, \\ Pasadena, CA 91105, USA
}

\begin{abstract}
A new micromachined cell lysis device is developed. It is designed for miniature bio-analysis systems where cell lysing is needed to obtain intracellular materials for further analysis such as DNA identification. It consists of muti-electrode pairs to apply electric fields to cells. We adopt the means of using electric field lysing because it can greatly simplify purification steps for preparation of biological samples, when compared to conventional chemical methods. Yeast, Chinese cabbage, radish cells and $E$. coli are tested with the device. The lysis of yeast, Chinese cabbage, radish cells is observed by a microscope. The experimental observation suggests $E$. coli are also lysed by the pulsed electric field. The range of electric field for the lysis is on the order of $1 \mathrm{kV} / \mathrm{cm}$ to $10 \mathrm{kV} / \mathrm{cm}$. In addition, for practical reasons, we reduce the voltage required for lysing to less than $10 \mathrm{~V}$ by making the electrode gap on the order of microns.
\end{abstract}

\section{INTRODUCTION}

Cell lysing is defined as disrupting cells by physical, chemical, mechanical or enzymatic means in order to obtain intracellular materials. Physical means includes osmotic shock or pressure. Detergents, solvents and antibiotics are used for the chemical method. Mechanical shear methods are also used to disrupt cells [1]. The most common method used in biotechnology labs is the chemical method because the protocols are well established. Interestingly, cell lysing by pulsed electric fields has been reported using macro electroporation systems, but a micro device for doing so has not yet been developed [ $2-4]$. The applications of electroporation have included the introduction of both foreign DNA and RNA to a variety of plant, animal, bacterial, and yeast cells. The electric field makes micro-pores on the cell membrane and cells permeable to the medium so that DNA or RNA can be introduced into cells. The micro-pores are resealable in a moment. If the electric field is high enough, it will cause the irreversible breakdown of the cell membrane and will sometimes lyse cells. The goal of this project is the development of a micro cell-lysing device that will be used on a small number of cells. It can greatly reduce purification steps for preparing bio-samples in comparison to chemical method. It also implies the reduction of the number of valves and pumps when a micro bio-analytic system is developed. The micro cell lysis device can reduce the voltage required for cell lysis because the electrode gap can be easily fabricated in a size comparable to the size of biological cells.

\section{Theory}

The bilayer structure of a cell membrane is a dielectric. When a cell is exposed to an external electric field, a
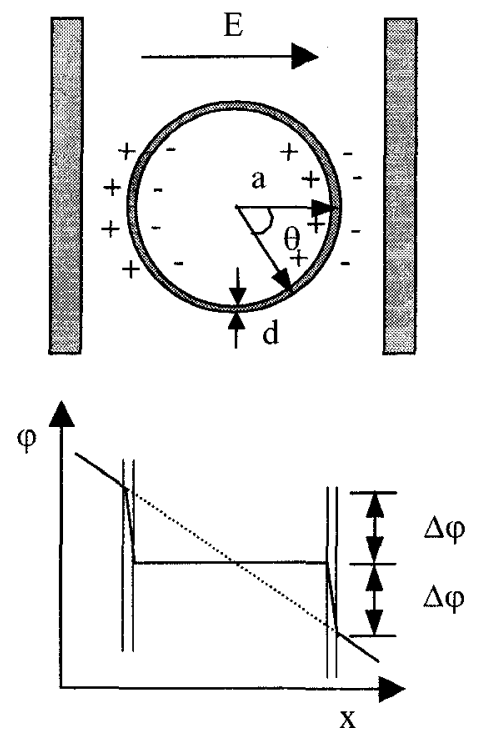

Fig.1 Induction of a transmembrane potential

transmembrane potential, $\Delta \varphi$, is induced. Fig. 1 shows the induction of transmembrane potential. If the transmembrane potential is higher than about $1 \mathrm{~V}$, the membrane are permeable to the outside medium. For a spherical cell of radius $a$, the transmembrane potential can be expressed as $[3,5,6]$

$\Delta \varphi=1.5 a E \cos \theta$

where $E$ is the applied electric field strength and the angle, $\theta$, is between the field line and the normal to the point of interest in the membrane. The mechanism of 
electroporation is not fully understood. The most widely accepted model for electroporation, the electromechanical compression of the cell membrane, was proposed by Zimmermann [7, 8]. The attraction of opposite charges induced on the inner and outer membrane generates compression pressure, which makes the membrane thinner. If the electric field strength exceed a critical value, when the transmembrane potential is approximately $1 \mathrm{~V}$, the cell membrane becomes permeable to the medium. The poration of cell membrane can be reversible or irreversible depending on the electric field strength and duration of pulse. The irreversible breakdown of membrane cause cell membranes to burst open [9], or as the osmotic pressure of the cytosol and the external medium become unbalanced and the cells swell, the membrane is torn as a result of the over-swelling [3].

\section{DESIGN AND FABRICATION}

The schematic operation of the device is shown in Fig. 2. The way of using the device is as follows. First, the cells and the medium are pumped into the channel. Next, the cells are attracted to the sharp point of the electrode by dielectrophoretic force using AC voltage. Then, they are lysed by pulsed electric fields. The edge of the electrodes is sharp in order to have field

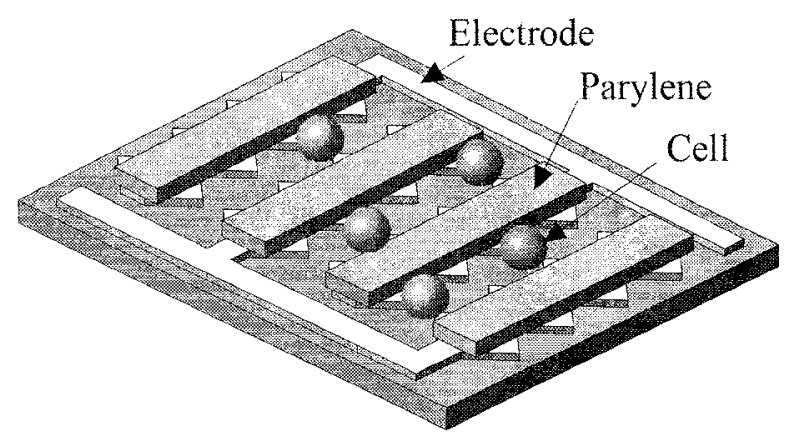

Fig. 2 Schematic view of cell lysis device

concentration. The gap between electrodes in our device is $5 \mu \mathrm{m}$. Parylene is used to make blocks between electrode pairs.

The fabrication sequence of the cell lysis device is shown in Fig. 3. A $5000 \AA$ silicon dioxide is thermally grown on a silicon substrate. $\mathrm{Cr} / \mathrm{Au}(200 \AA / 5000 \AA)$ is thermally evaporated and patterned for electrodes. $4 \mu \mathrm{m}$ thick poly-p-xylylene (Parylene C) - is deposited and patterned to make blocks between electrode pairs. Then the device is bonded to a glass substrate with inlets, outlets and channel. The $30 \mu \mathrm{m}$ high channel in the glass was made by timed wet etching in buffered HF. For attaching tubes, $750 \mu \mathrm{m}$ inlet and outlet holes are made by drilling. Silastic tube whose inner diameter is $300 \mu \mathrm{m}$ is connected to the holes. The photograph of the fabricated and packaged device is shown in Fig. 4 and 5 , respectively.

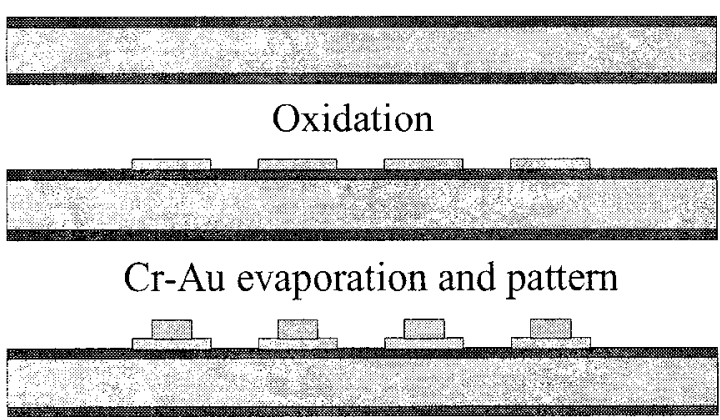

Parylene $\mathrm{C}$ deposition and pattern

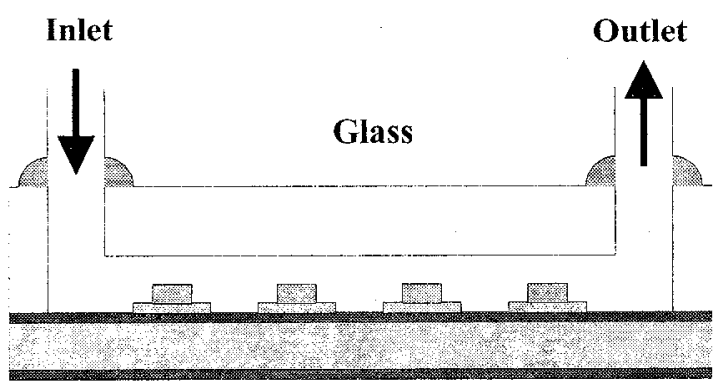

Packaging with glass channel

Fig. 3 Fabrication steps and fully packaged device

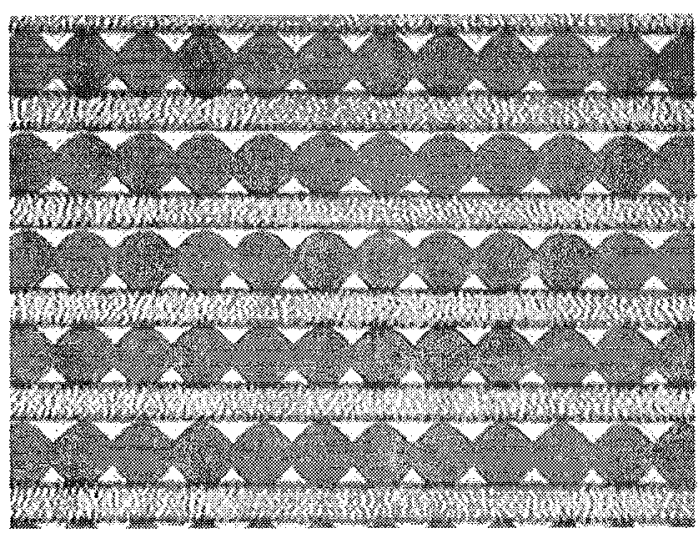

Fig. 4 Photograph of a fabricated device

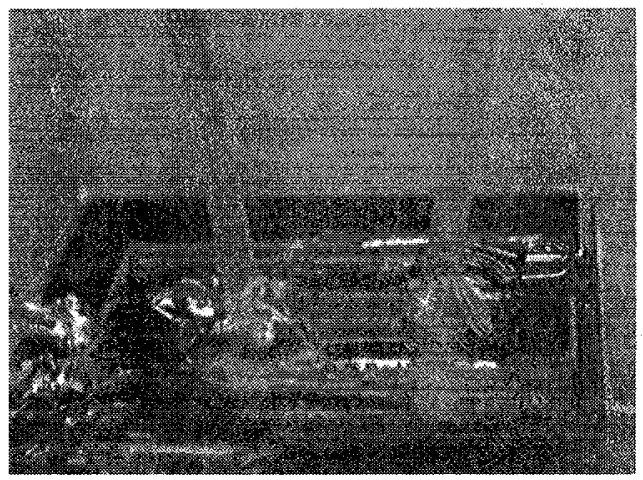

Fig. 5 Photograph of a fabricated device 


\section{LYSING EXPERIMENTS AND RESULTS}

The pulse generator was made with multivibrator circuits, a solid-state relay and a power MOSFET. A typical waveform is shown in Fig. 6. The pulse duration and timing are controlled by multivibrators (74LS123).

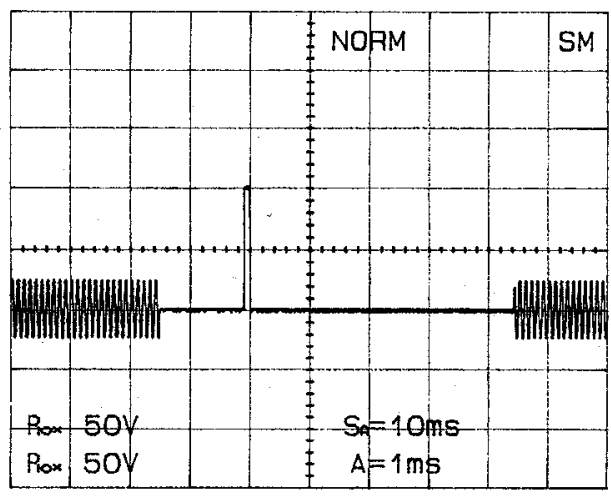

Fig. 6 Plot of waveform for cell lysis

Yeast (Saccharomyces cerevisiae) protoplasts and Escherichia coli (strain ATCC 25922) were tested for lysis. Cabbage and radish protoplasts were also examined with a different type of electrodes. The lysis of yeast cells, cabbage and radish protoplasts was observed and determined under a microscope. In case of E. coli, a certain volume of the lysed cells was collected to test their viability after applying the lysing voltage.

\section{Yeast cells}

Fig. $7 \mathrm{a}$ and $7 \mathrm{~b}$ show the yeast cells before and after applying pulsed voltages. The diameters of cells are in the range of $4-6 \mu \mathrm{m}$. Fig. $7 \mathrm{a}$ shows the when $2 \mathrm{MHz}$, $6 \mathrm{~V} \mathrm{AC}$ voltage is applied. The yeast cells are attracted to the electrodes. Fig. $7 \mathrm{~b}$ shows that, after lysing the cells, they cannot be attracted to the electrodes using the $2 \mathrm{MHz}$ AC voltage [9]. The lysis of yeast cells is also examined by the microscope as cells are collected just after lysis. Fig. 7c shows yeast cells that are not exposed to the electric fields and Fig. 7d shows the cells after lysing. In Fig 7d, only membrane debris is found after pulsed electric field treatment. The black dots in Fig. 7d are cell debris. Fig. 8 shows the lysing rate with different electric fields and pulse duration. The rate increases with higher lysing voltage and duration. However, excessive pulse voltage and duration can cause electrolysis which generates bubbles. The optimum value for yeast cell lysing was achieved at $100 \mu$ s and $20 \mathrm{~V}$.

\section{E. coli}

A pure colony of $E$. coli was incubated overnight in Tryptic Soy Broth (Difco L/N 104073JB). The sizes of

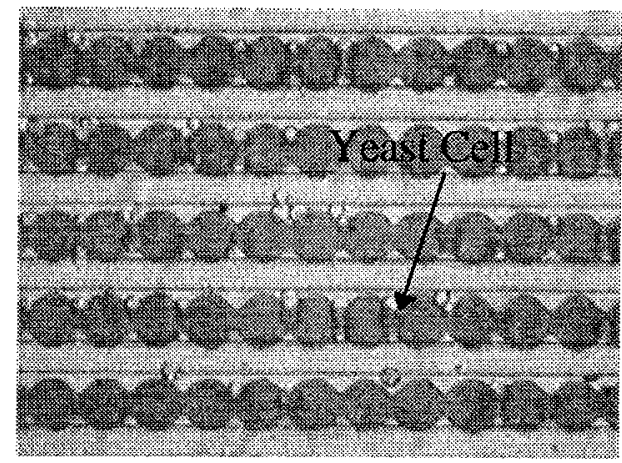

(a) Before pulsed voltage

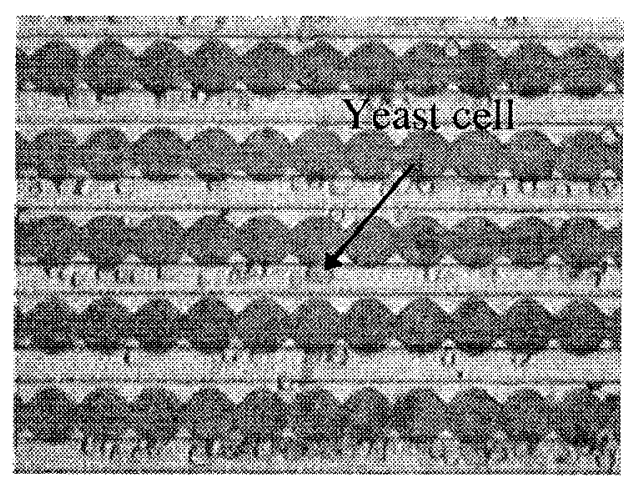

(b) After pulsed voltage

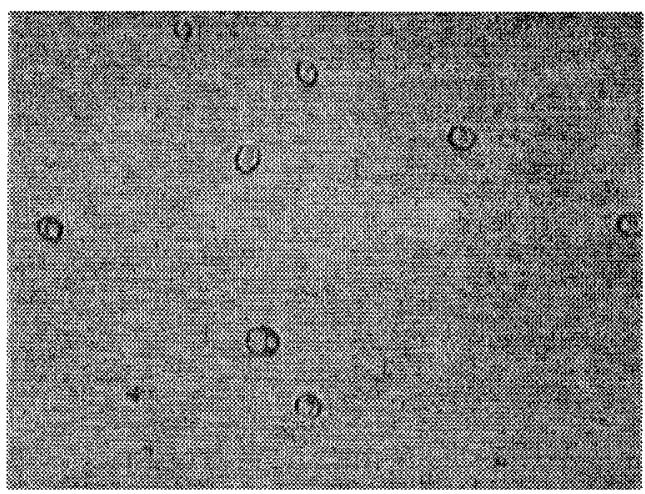

(c) Yeast cells not treated by pulsed voltage

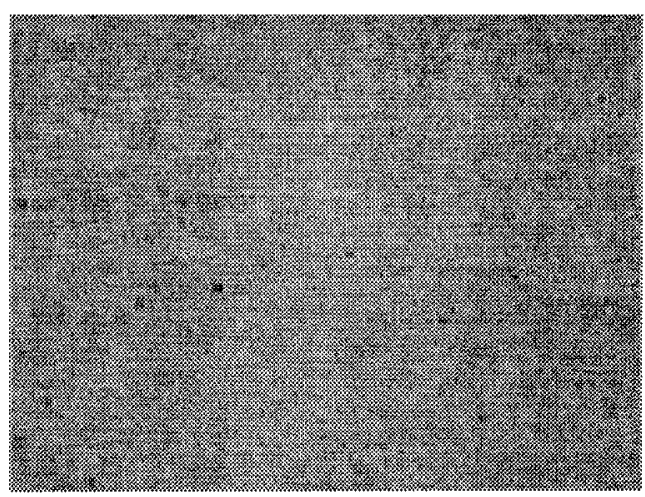

(d) Collected yeast after treatment of pulse

Fig. 7 Photograph of yeast cells before and after lysing 


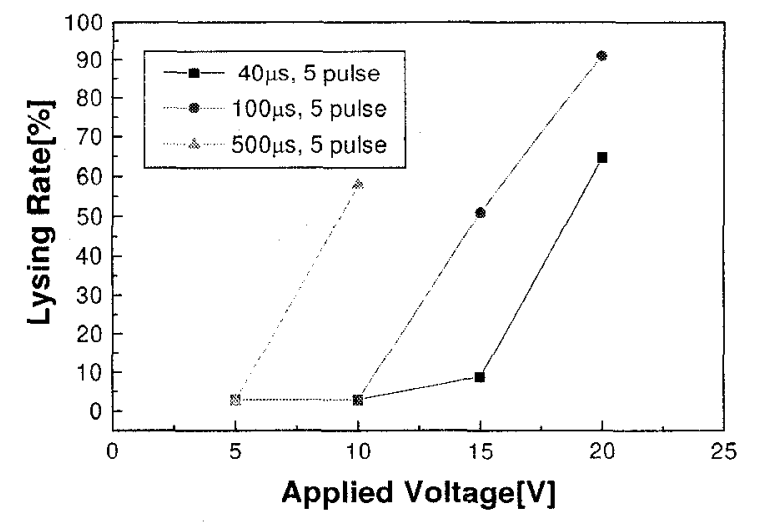

Fig. 8 Plot of lysing rate for yeast cells

cells are between $2-4 \mu \mathrm{m}$. To ensure that the cells are lysed, the pulsed voltages were continuously applied while the $E$. coli cells were slowly injected at the inlet. A $3.5 \mathrm{~V} 500 \mu$ s pulse was applied every two seconds. Higher voltage than $3.5 \mathrm{~V}$ caused. It is very difficult to visibly determine by the microscope if cells are lysed or not. As a result, the cells were collected and cultured on Tryptic Soy agar plate (Difco L/N 97898JD) overnight to observe if the cells were actually lysed. Fig. 9 shows the photograph after the 24 hour incubation of cells. The cells without the pulse treatments grew in the left petri dish, but cells given the pulse treatments did not (right petri dish). This suggests that $E$. coli cells were also lysed.

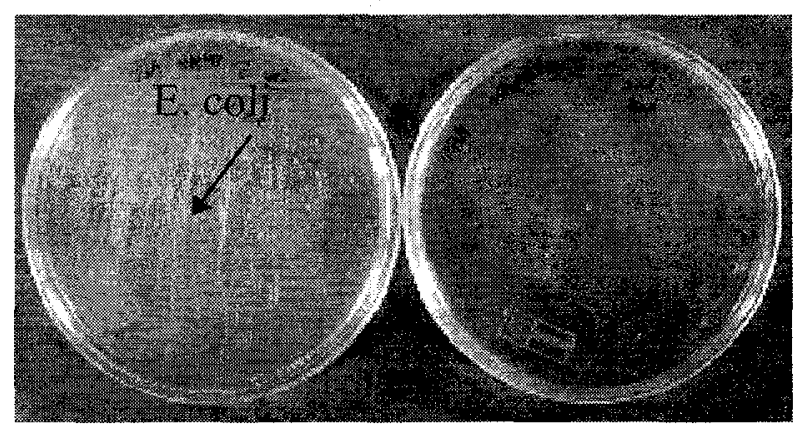

Fig. 9 Photograph of incubated E. coli cells

\section{Chinese cabbage and radish protoplasts}

Chinese cabbage and radish protoplasts were prepared by removing cell walls in an enzyme solution. The average diameters of cells are 30 and $35 \mu \mathrm{m}$, respectively. The cells are pipetted to a $60 \mu \mathrm{m}$ gap electrodes. Lysis of cells using AC voltage was observed above $880 \mathrm{~V} / \mathrm{cm}$ for radish cells and $590 \mathrm{~V} / \mathrm{cm}$ for Chinese cabbage cells at $1 \mathrm{MHz}$. The cells were deformed and eventually burst. A Chinese cabbage cell is attracted on the electrode by dielectrophoretic force in Fig. 10a. It is lysed when the voltage is increased and shown in Fig. 10b. The pulsed electric field alio lysed cells immediately after application. With $1 \mathrm{~ms}$ square pulse, Chinese cabbage cells are lysed above $1.5 \mathrm{kV} / \mathrm{cm}$ and radish cells above $1.75 \mathrm{kV} / \mathrm{cm}$. Larger cells are more easily lysed in low electric fields than smaller cells. Table 1 shows a summary of the lysing conditions of our experiments. Lysis or deformation of yeast and E. coli were not observed until $21 \mathrm{kV} / \mathrm{cm}$ at $2 \mathrm{MHz}$.

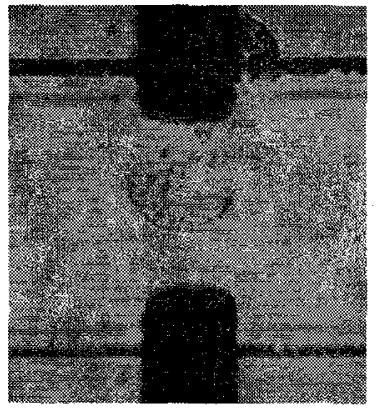

(a)

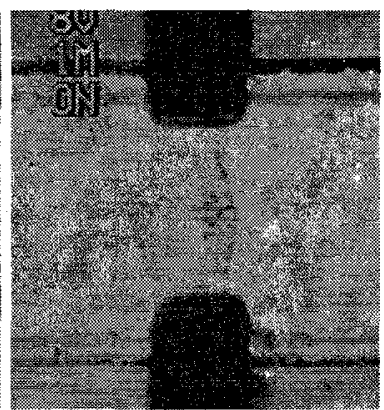

(b)
Fig. 10 Photograph of lysing Chinese cabbage cell

Table 1. Summary of Lysis condition

\begin{tabular}{|l|l|l|}
\hline & \multicolumn{1}{|c|}{$\mathrm{AC}$} & \multicolumn{1}{|c|}{$\begin{array}{c}\text { DC } \\
\text { (square pulse) }\end{array}$} \\
\hline $\begin{array}{l}\text { Chinese cabbage } \\
\text { protoplasts }\end{array}$ & $\begin{array}{l}>590 \mathrm{kV} / \mathrm{cm} \text { at } \\
1 \mathrm{MHz}\end{array}$ & $\begin{array}{l}>1.5 \mathrm{kV} / \mathrm{cm} \text { at } \\
1 \mathrm{~ms}\end{array}$ \\
\hline $\begin{array}{l}\text { Radish } \\
\text { protoplasts }\end{array}$ & $\begin{array}{l}>880 \mathrm{kV} / \mathrm{cm} \text { at } \\
1 \mathrm{MHz}\end{array}$ & $\begin{array}{l}>1.75 \mathrm{kV} / \mathrm{cm} \text { at } \\
1 \mathrm{~ms}\end{array}$ \\
\hline $\begin{array}{l}\text { Yeast } \\
\text { protoplasts }\end{array}$ & $\begin{array}{l}\text { Not observed up } \\
\text { to } 21 \mathrm{kV} / \mathrm{cm} \text { at } 2 \\
\mathrm{MHZ}\end{array}$ & $\begin{array}{l}>10 \mathrm{kV} / \mathrm{cm} \mathrm{at} \\
100 \mu \mathrm{s}\end{array}$ \\
\hline E. coli & $\begin{array}{l}\text { Not observed up } \\
\text { to } 21 \mathrm{kV} / \mathrm{cm} \text { at } 2 \\
\mathrm{MHZ}\end{array}$ & $>7 \mathrm{kV} / \mathrm{cm} \mathrm{at}$ \\
\end{tabular}

\section{DISCUSSION}

Cell lysis by electric field can be performed with AC or DC electric fields. Some difference in lysis between the microbials on the order of few $\mu \mathrm{m}$ versus the plant cells on the order of $20-40 \mu \mathrm{m}$, is observed. The protoplasts of plant cells are stretched by AC electric fields; dielectrophoretic force pulls the cells between the electrodes. The cell membranes can be torn out if the strength of electric filed is high enough. For yeast and $E$. coli, cell lysis by $\mathrm{AC}$ electric fields, up to 20 $\mathrm{kV} / \mathrm{cm}$, was not observed. The dielectrophoretic force on the cells was not high enough to breakdown the cell membrane because the surface to volume ratio is higher than in the plant cells. For lysis by DC, the plant cells 
are instantly burst open and lysed by pulsed electric fields. Yeast cells show negative dielectrophoresis after being exposed to a pulsed electric field and have a spherical shape, but the color is slightly different. Normal cells are not observed after collecting the cells. It supports Tsong's theory [3]: the osmotic pressures inside and outside the cells are unbalanced causing the cells to swell and eventually burst due to over-swelling [3].

\section{CONCLUSION}

Cell lysing has been demonstrated with the micromachined cell lysis device. This device is promising for cell lysing and can be used for bioanalysis systems. The protoplasts of cells are lysed by $\mathrm{AC}$ and DC electric fields. The microbials are mostly lysed by pulsed electric fileds

\section{ACKNOWLEDGMENTS}

This work is supported by the DARPA MICROFLUMES program under Naval Ocean Systems Center Contract N66001-96-C-83632. The authors would like to thank Xing Yang for help with processing.

\section{REFERENCES}

[1] Biochemical Engineering and biotechnology handbook, Stckton press, New York, 1991, pp. 939-945.

[2] U. Zimmermann, P. Scheurich, G. Pilwat, and R. Benz, "Cells with manipulated fuctions: New perspectives for cell biology, medicine and technology," Angew. Chem. Ed. Engl., Vol. 20, pp. 325-345, 1981.

[3] T. Y. Tsong, "Electroporation of Cell Membranes: Mechanism and Application," in: Electroporation and Electrofusion in Cell Biology (E. Neumann, A. E. Sowers, and C. A. Jordan, ed.), Plenum Press, New York, 1989, pp. 149-163.

[4] G. W. Bates, "Electrofusion of Plant Protoplast and the production of Somatic Hybrids," in: Guide to Electroporation and Electrofusion (D. C. Chang, B. M. Chassy, J. A. Saunders, and A. E. Sowers, ed.), Academy Press Inc., New York, 1989, pp.249-264.

[5] H. Pauly, and W. P. Schwan, "Dielectric properties and ion mobility in erythrocytes," Biophys. J. Vol. 6, pp.621-639, 1966.

[6] P. Lindner, E. Neumann, and K. Rosenheck, "Kinetics of permeability changes induced by electric impulses in chromaffin granules," J. Membr. Biol. Vol. 32, pp. 231-254, 1977.

[7] U. Zimmermann, "Electrical breakdown, electropermeabilization and electrofusion," Rev.
Physiol. Biochem. Pharmacol. Vol. 105, pp. $75-$ $256,1986$.

[8] T. Grahl and H. Markl, "Killing of microorganisms by pulsed electric fields," Appl. Microbio. Biotechnol., 45, pp. 148-157, 1996.

[9] S. W. Lee, A study of fabrication and applications of micromachined cell manipulating devices, Ph.D. Thesis, Seoul National University, 1996. 